\title{
Prosopographica IV
}

\author{
Nikolaos Gonis*
}

\begin{abstract}
A sequel to a series of notes on high-ranking persons in Late Antique Egypt, continued from APF 65 (2019) 348-56. Full editions of two papyri briefly described in P.Lond. III are given in an Appendix.
\end{abstract}

Keywords: Prosopography, Late Antiquity, Hermopolis, Antinoopolis, vir clarissimus, comes, scholasticus, ex-praesides, exceptor

https://doi.org/10.1515/apf-2021-0006

\section{Callinicus, comes}

In the previous instalment of these notes, I discussed the Hermopolite dossier of Callinicus, vir clarissimus, and briefly alluded to the comes of this name (APF 65 [2019] 352-3). The latter is recorded in PLRE IIIA 264, Callinicus 9, from P.Lond. III 1314a and 1325, both known as descripta of unknown provenance at that time. The first of these two papyri is now SB XX 14169 , a tax receipt issued by the comes and apparently addressed to a functionary of the Hermopolite village of Telbonthis, some time in the sixth century. A scriniarius and an exceptor sign the receipt; as these officials normally served on the staff of provincial governors or duces, we may assume that Callinicus held a senior post in the fiscal administration of the Thebaid. A full edition of the second text is offered in the appendix below.

An additional attestation of this comes may come from P.Ant. III 189, a list of wanted persons from 'various villages' of a comes Callinicus, as-

Vorbemerkung: The papyri published in this article were studied from a microfilm and then from digital images, reproduced here by permission of the British Library Board. My thanks to Federica Micucci for help with remote study.

* Kontakt: Nikolaos Gonis, Department of Greek and Latin, University College London, London WC1E 6BT, <n.gonis@ucl.ac.uk> 
signed to the sixth/seventh century. Though the papyrus was found in Antinoopolis, these villages lay in the north of Hermopolis. Whether he is to be identified with the pagarch in P.Münch. III 152 or the $d u x$ of the Thebaid in the late $560 \mathrm{~s}$, it cannot be decided on current evidence. ${ }^{1}$

\section{Hermopolite Anatolii}

There are several entries in PLRE II and III about persons called Anatolius, attested in papyri of the fifth, sixth, and seventh centuries. PLRE II 84, Anatolius 7, records a Hermopolite vir spectabilis from P.Princ. III 137.

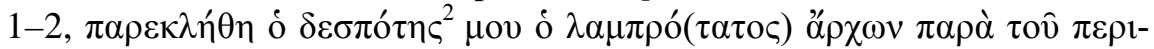

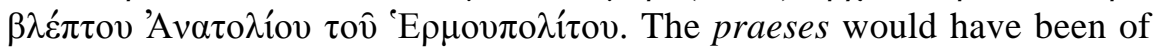
the Thebaid or even of Arcadia; his clarissimate suggests a date not later than the end of the fifth century, which is in line with the handwriting. A spectabilis would have probably risen to this rank from that of clarissi$m u s$, but it is unclear whether he is the same as any of the other clarissimi of this name. An Anatolius, v.c., gave his name to a Hermopolite fiscal division ( $\mu \varepsilon \rho i ́$ ) some time in the fifth century (BGU XII 2170.3), found also in accounts of the sixth and seventh centuries (SB XXII 15634.9, P.Würzb. 19.4). ${ }^{3}$ If this Anatolius had become a spectabilis, he would have left his traces in the account books. Another Anatolius, v.c. (PLRE IIIA 73, A. 9), is known from BGU XII 2194.1; the text was assigned to the sixth century, which is plausible, and suggests a different person from the other two. But what to do with the comes of this name in P.Lond. V 1800-1802 (PLRE IIIA 70, Anatolius 1)? Bell assigned these three documents to the '5th-6th century' on palaeographical grounds, and pointed to the Hermopolite nome as their possible origin on the basis of a monetary term. The format of the texts and the name Hermapollon (1801.2, 1802.2) lend further support to the suggested provenance. The reference to talents of silver seems to rule out a date after the mid sixth century.

\footnotetext{
${ }^{1}$ See J. Banaji, Agrarian Change in Late Antiquity: Gold, Labour, and Aristocratic Dominance $\left({ }^{2} 2007\right) 165,253$. On this dux, see J.-L. Fournet, Hellénisme dans l'Égypte du VI $I^{e}$ siècle: La bibliothèque et l'oeuvre de Dioscore d'Aphrodité (1999) 332-6, esp. 336 n. 552 .

${ }^{2} \delta \varepsilon \sigma \pi$ ó $\tau \eta<\zeta>e d . p r$.; to judge from the online image, the scribe reinked his pen after writing sigma, retraced the lower part of eta, and continued with $\mu$ ov.

${ }^{3}$ On these $\mu \varepsilon \rho i ́ \delta \varepsilon \varsigma$ see J. Gascou \& P.J. Sijpesteijn, 'P.Berol.G 25003: Deux documents fiscaux hermopolites', ZPE 97 (1993) 119-21.
} 
Bell had associated this comes with the 'Count of Arcadia' of P.Lond. III 1073, which seems to be later in date. This is PLRE IIIA 73, Anatolius 10: 'Addressee of a petition on a civil matter; the document is of unknown

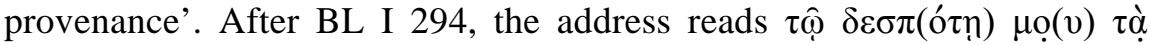

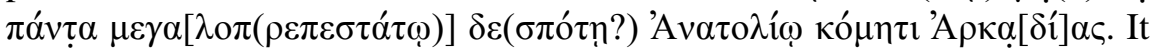
was thought that Anatolius was a praeses Arcadiae, but his mediaeval sounding title has no parallel in papyri. This disappeared after the last

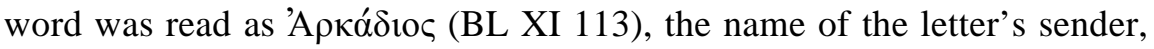

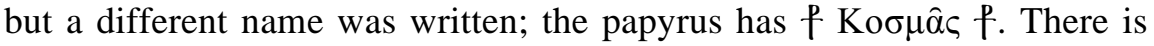
also no $\delta \varepsilon(\sigma \pi$ óṭฺ?) but remains of an inked seal.

Originally placed in the sixth century, P.Lond. 1073 was more recently assigned to the seventh. ${ }^{4}$ The uncertainty about its provenance led to a separate entry in PLRE IIIA 73, Anatolius 11, for the comes addressed in the letter P.Grenf. I 64, assigned to the sixth/seventh century and possibly

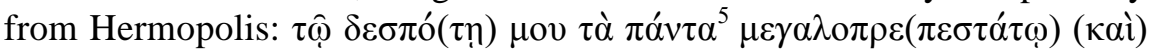

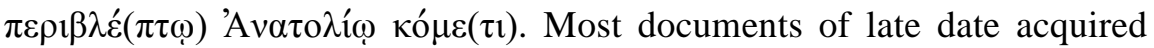
with P.Lond. 1073 come from Hermopolis, and it would be economical to identify the addressees of these two letters. Even more, there are several entries for a comes Anatolius and his wife in P.Sorb. II 69 (see $11.45 \mathrm{n}$. there), a tax account of $618 / 19$ or $633 / 4$.

Another letter referring to the same comes, acquired by the British Museum at the same time as P.Lond. 1073, is P.Lond. 1069a, published in the appendix below. The sender, the exceptor Colluthus, is probably also known from P.Sorb. II 69. Assuming that all references are to the same comes, we may place Anatolius in the earlier part of the seventh century.

Comites at that time were generally spectabiles, and the one in P.Grenf. I 64 is called $\pi \varepsilon \rho 1 \beta \lambda \varepsilon \dot{\varepsilon}(\pi \tau \omega)$. The addressee of P.Lond. 1069a is styled $\pi \alpha v-$ $\varepsilon v \varphi n \mu(\omega)$. This epithet (famosissimus) applied to persons of the highest senatorial grade, normally consulares and patricii; it is also used of duces, but this is due to the status of the person, not the function. A comes is of lower rank, including the holders of the comitiva domesticorum (the point of entry to the illustres), who disappear in the second half of the sixth century. $\pi \alpha v \varepsilon v \varphi \eta ́ \mu(\omega)$ may have been used for flattery, in a letter conveying a request.

\footnotetext{
${ }^{4}$ F. Morelli, 'Grammatêphoroi e vie della giustizia nell'Egitto tardo antico', Symposion 2005 (2007) 357.

${ }^{5}$ New reading, made on a photograph, in place of $\tau \hat{\alpha}$ ก $\pi \alpha v^{\alpha}(\omega v)$ of BL I 185; the papyrus has $\tau^{\alpha} \pi \alpha \nu \tau$ s.
} 


\section{Anonymus 73, scholasticus}

This is the appelation given in PLRE IIIB 1440 to a '?vir gloriosus (Egypt); advocatus (fori Thebaidis)'. He was the father of the exceptor Fl. Theodorus in P.Cair.Masp. III 67312.6-7, a will written in Antinoopolis in 567:

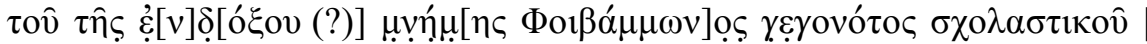

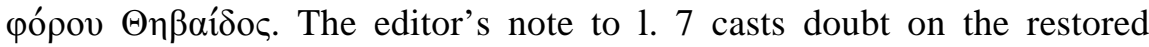
name: 'La restitution «Phoibammôn » paraît peu possible pour le nom, quoique l'avocat Phoibammôn soit connu par plusieurs papyrus publiés plus haut.' PLRE rules out the identification with 'Phoebammon 7 (PLRE IIIB 1033-4) on chronological grounds, and an image shows that the name was not Phoibammon. After a space wide enough for six of seven letters, with some specks scattered here and there, there is a tall upright followed by traces of two more letters; perhaps the name ended in ].o s.

This man was not a vir gloriosus when he was alive. Under the sigma of $\tau \hat{\eta} \varsigma$ one can see the tip of an oblique stroke rising from left to right, which

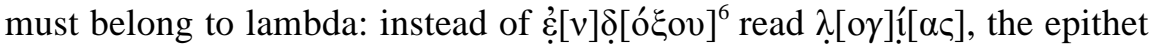
commonly used for the 'memory' of late scholastici.

\section{Demeas, comes and ex-praeses, and others}

P.Laur. II 34 is a rent receipt of unknown provenance, assigned to the second half of the sixth century. It begins $\pi(\alpha \rho \grave{\alpha}) \Delta \eta \mu \varepsilon ́ \alpha \varsigma$ кó $\mu \eta \tau(о \varsigma) \kappa \alpha \grave{~}$

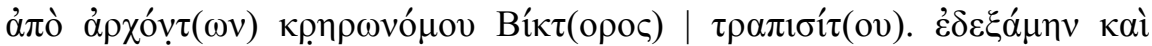

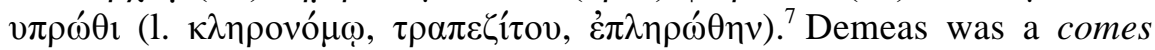
and ex-praeses, but receives no entry in PLRE III. We do not know where he served as governor, but this receipt shows that he was based in the The-

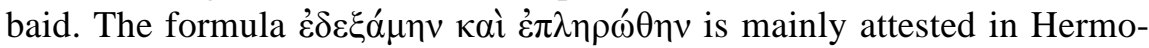
polite texts, but there are also examples from Antinoopolis and Aphrodito. The name $\Delta \eta \mu \varepsilon \dot{\varepsilon} \alpha$ is also fairly common in Hermopolis, and was borne by

\footnotetext{
${ }^{6}$ I referred to this passage in 'Korr. Tyche 570. Superlatives for the Deceased', Tyche 22 (2007) 215 (= BL XIII 570), but realized too late that the text corrected was that of the older DDbDP version; ed. $p r$. did not have the superlative.

${ }^{7}$ This is a revised text. The editor thought that Demeas was an heir and the receipt was

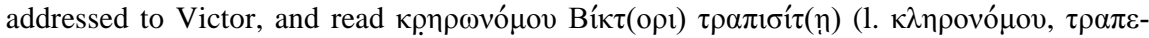

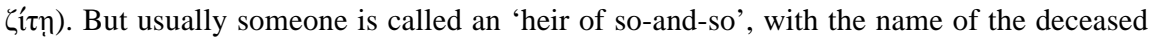

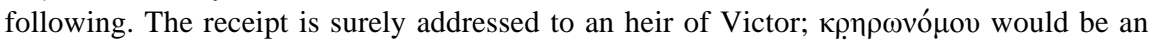

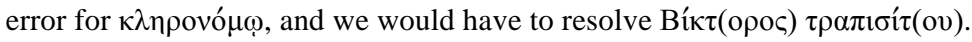


high-ranking persons there. ${ }^{8}$ It is unfortunate that we cannot go beyond the assigned date, which is also in line with the sum paid for rent, $2 \frac{1 / 4}{4}$ carats. As we saw above, Egyptian comites in the late sixth and early seventh centuries were not the important grandees of earlier times. The кó $\mu \eta \varsigma$ кaì

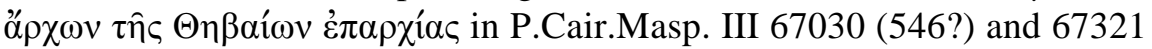
(548/9?), who bears these titles in official documents, is not exactly comparable. Was Demeas really a former governor?

Only two other Egyptian ả $\pi$ ò $\alpha \rho \chi o ́ v \tau \omega v$ are recorded in PLRE III; three others have become known since then, ${ }^{9}$ but those two are the most interesting. The first is Fl. Ioannes qui et Lampadius 92, '?signifer of Arcadia and ex praesidibus', whose 'title of à $\mathrm{ò}_{\mathrm{\alpha}}^{\mathrm{\alpha} \chi o ́ v} \tau \omega \mathrm{v}$ is honorific', PLRE IIIA 677 asserts. PLRE IIIA 734 is slightly more circumspect about Iulianus 13:

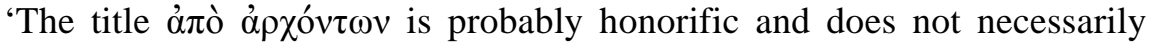
imply that he had once been a provincial governor'. But why should this title be honorific? As far as I can see, there is no unambinguous example of an honorary praeses; in view of the nature and status of the office in

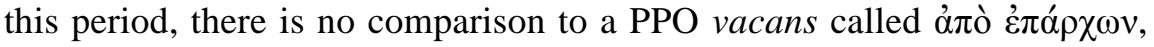
an $\dot{\alpha} \pi$ ò $\dot{\pi \alpha ́} \tau \omega v$ who did not hold a consulship, or a $\sigma \tau \rho \alpha \tau \eta \lambda \alpha ́ \tau \eta\rceil$ without a career in the army. I wonder whether the idea that the title was honorific stems from the other functions of these persons, which might have appeared too lowly in comparison. ${ }^{10}$ Iulianus was a pagarch of Antaeopolis in 553, but held the post with a glorisissima femina $;{ }^{11}$ and certain sixthcentury Arsinoite pagarchs were of much higher status than any praeses. As for Fl. Ioannes alias Lampadius, attested in Oxyrhynchus 579, he has been shown not to be a signifer but a scholasticus (no doubt an advocatus

\footnotetext{
${ }^{8}$ Such as the scholasticus and defensor civitatis in the early sixth century (SB XVI 12699 and XX 14456; BGU XIX 2822) or the vir clarissimus in the early seventh (P.Sorb. II 69.19.A19, 46A.11, 15, 65C.6; there is no reason to identify him with the ex-praeses).

${ }^{9}$ All three occur in tax registers from Hermopolis. Better known are Demetrios and Phoibammon, on whom see J.-L. Fournet, 'Un nouvel épithalame de Dioscore d'Aphrodité adressé à un gouverneur civil de Thébaïde', AnTard 6 (1998) 80 (on Demetrios, see further my 'Prosopographica II', APF 55 [2009] 94). The other is Sarapion (SB XVIII 13758r.34; strictly speaking, the first edition of this text predates PLRE III).

${ }^{10}$ A similar concept underlies the discussion of Theodosius 15, PLRE IIIB 1294, another possible governor, who 'may perhaps have been one of the wealthy landowners who feature in the papyri in this period as bearers of imperial titles which were honorific and did not imply the tenure of any actual office'.

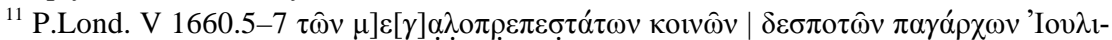

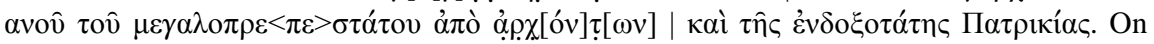
the dossier of Iulianus, see Fournet (above, n. 9) 80.
} 
too) attached to the forum of Arcadia. ${ }^{12}$ Why would a senior professional not have been a praeses? The status of civilian provincial governors was not particularly high already in the fifth century. The praeses cuts a peripheral figure in the world of Dioscorus, ${ }^{13}$ and the epithets used for the $d u x$ and the praeses in SB XXVI 16519 (VI/VII) demonstrate the significant

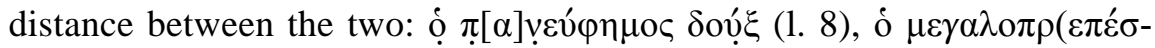
$\tau \alpha \tau o \varsigma) ~ \alpha ’ \rho \chi \omega v ~(1.24)$. It would be preferable to take the title $\dot{\alpha} \pi$ ò $\alpha \rho \chi o ́ v \tau \omega v$ at face value, and to try to understand the circumstances of the people who held such posts.

\section{Serenus, comes}

P.Rain.Cent. 80, a sixth-century letter found in Hermopolis, is addressed

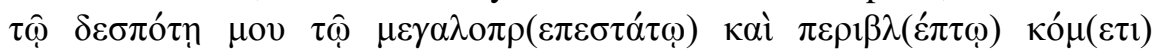
$\ldots v \omega$. The online image suggests that the name of the comes may be read as $\sum \varepsilon \rho ̣ v^{\prime} \omega$. No comes Serenus had been attested in Hermopolis. ${ }^{14}$

\section{APPENDIX}

\section{Two London Letters}

\section{To Georgius from a 'brother'}

BL Pap. 1325

$30.5(\mathrm{w}) \times 12.4(\mathrm{~h}) \mathrm{cm}$

Sixth century

The description of the papyrus in P.Lond. III, p. 1xxiii, reads: 'Official order or letter, with a reference to the comes Callinicus. 6th cent. Imperfect; in a large, rather sloping, cursive hand.' The address on the back tells us that a 'brother' writes to Georgios: two socially equals rather than actual

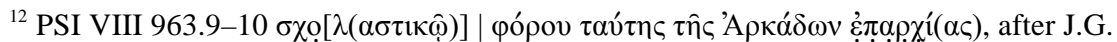
Keenan, 'Flavius John, Scholasticus: A Note on PSI 963', BASP 9 (1970) 16-18 (= BL VI 182). I take the opportunity to correct the mistaken identification of Fl. Ioannes alias Lampadius with Fl. Ioannes, scholasticus of the forum Arcadiae, proposed in P.Oxy. LXXXII 5340.5-6 $\mathrm{n}$. The two men had different fathers, which I missed when I revised the text for publication.

${ }^{13}$ Cf. Fournet (above, n. 1) 326.

${ }^{14}$ It is possible that there was a comes Serenus in Antinoopolis around 567 (PLRE IIIB 1123, Serenus 3), but this is probably the same as the Antaeopolite pagarch of this name; cf. Banaji (above, n. 1) 161, 253. 
brothers. A scholasticus seems to have handed papers concerning the village of Sinape to a domesticus; the comes Callinicus is given permission to go to an estate and bring forth some men. The writer asks Georgius to meet him in the evening or during the night. If Georgius finds out that the writer has gone to Antinoopolis, he will have to go to his house there. The writer assumed that the letter would be delivered before the evening, presumably of the day of writing. Someone from Hermopolis could go to and expect to be reachable at Antinoopolis on the same day, given the relative location of the two cities.

The papyrus was bought from Chauncey Murch on 20 November 1903.

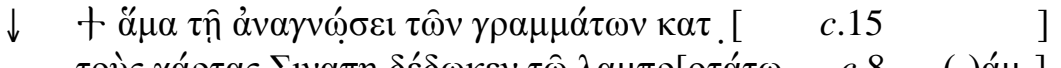

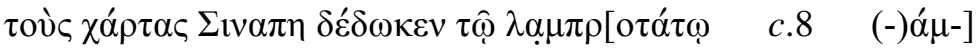

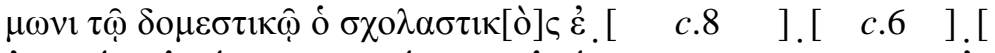

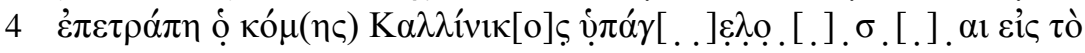

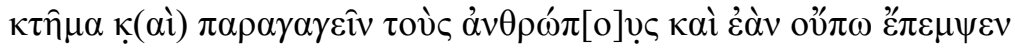

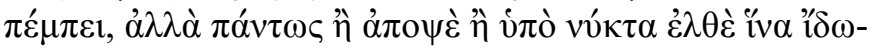

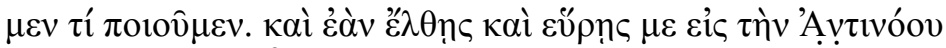

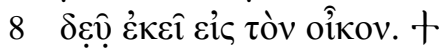

Back:

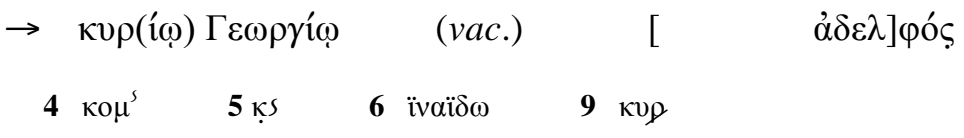

'Upon reading the letter ... The scholasticus has given the papers of Sinape to the clarissimus - ammon the domesticus ... The comes Callinicus was permitted to go(?) ... to the holding and to bring the men, and if he has not sent (them?) yet, he is sending (them?). But by all means come this evening or by night, so that we may see what we do. And if you come and find me in Antinoe, go there to the house.'

Back: 'To lord Georgius : ..., brother.'

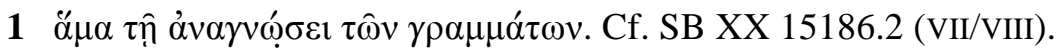

$\kappa \alpha \tau$.[. Probably a form of $\kappa \alpha \tau \alpha \lambda \alpha \mu \beta \alpha$ o $\omega$, perhaps in the imperative, followed by a place name: the sender would ask Georgios to go to where he is, as we see from the conclusion of the letter. 

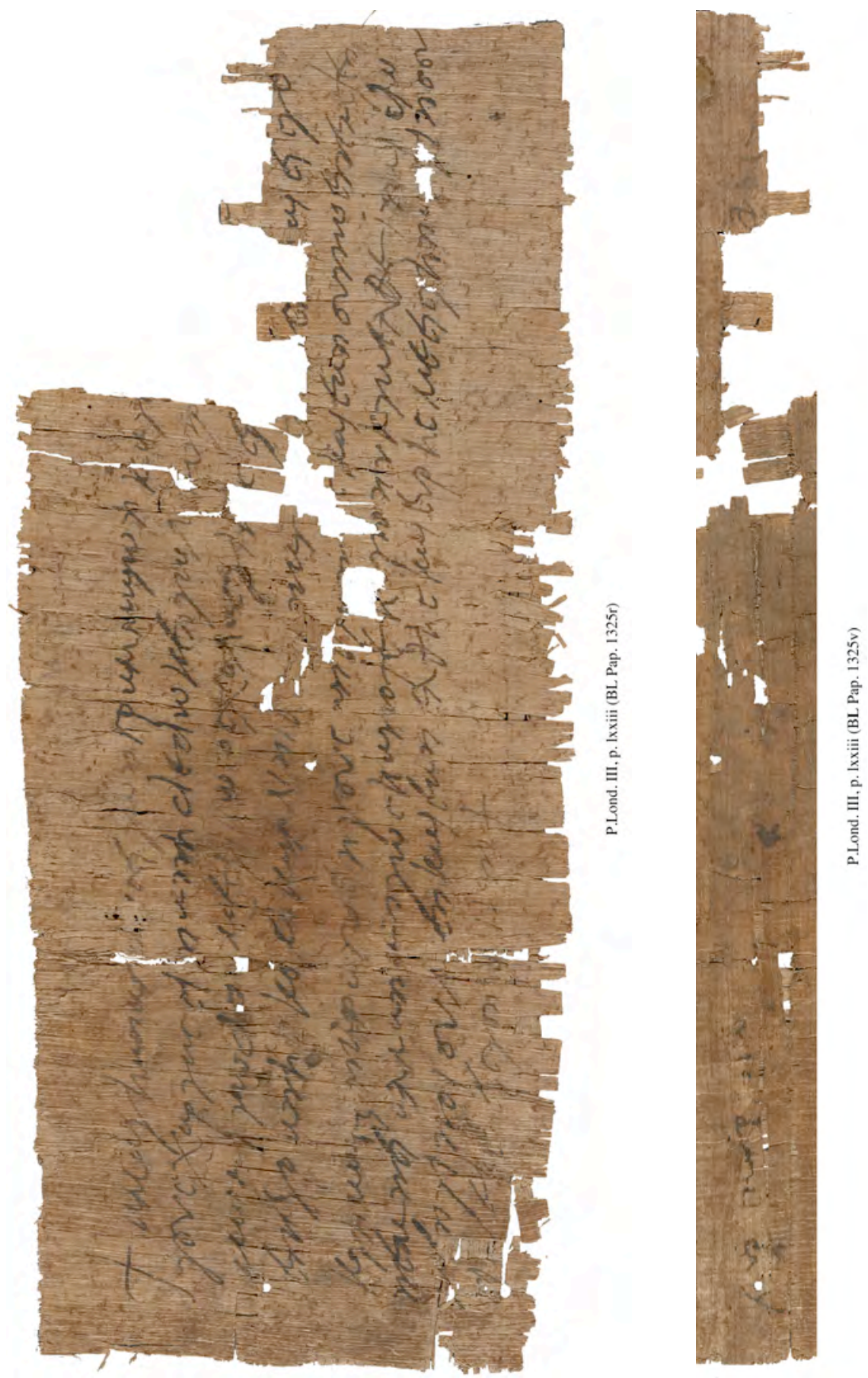


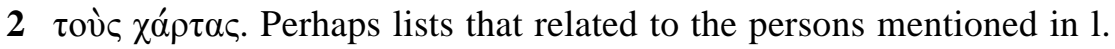
5 or legal documents about them, given the involvent of $\dot{\delta} \sigma \chi 0 \lambda \alpha \sigma \tau \iota \kappa[o ́] \varsigma$ in 3 (I take this to be the subject of $\delta \varepsilon \delta \omega \kappa \varepsilon v$ ).

$\Sigma \mathfrak{v} \alpha \pi \eta$. A village in the northern part of the Hermopolite nome (TM Geo 2938).

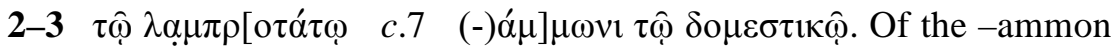

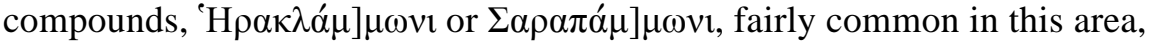
would take up most of the space available. This is the first instance in papyri of a domesticus honoured with the clarissimate. The one mentioned here would have been the assistant to a high-ranking civil or military officer, perhaps the praeses or dux. On domestici generally, see B. Palme, CPR XXIV 15 introd., pp. 98-9; F. Mitthof, SPP III ${ }^{2} .2$ 132.10-11 n.

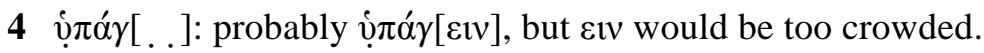

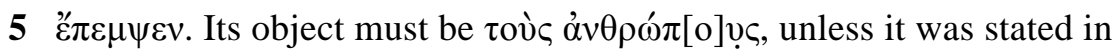
or implied from the damaged part of 1. 4.

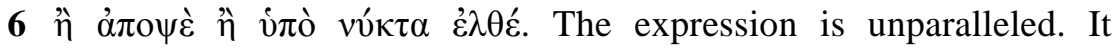
conveys the same urgency as requests that people act $\pi \rho$ ò $\delta 1 \alpha \varphi \alpha v ́ \mu \alpha \tau o \zeta$, as e.g. in SB XXVI 16358.6, from the archive of Senouthios. Cf. also CPR XXX 5, from the same archive, where Senouthios is asked to be in a certain place by midnight.

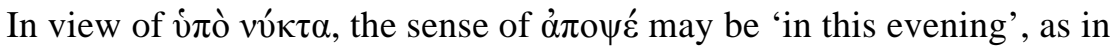
Modern Greek (accentuated $\dot{\alpha} \pi$ ó $\psi \varepsilon$ ), rather than generally 'in the evening'; cf. A. Papathomas, P.Heid. VII 408.3 n. It has ocurred in two other letters, both referring to written communications: P.Heid. 408.3 (IV/V)

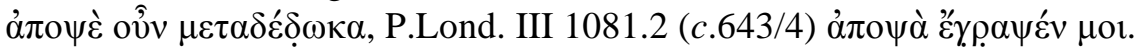

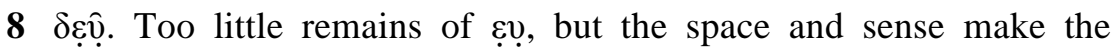
reading inescapable. $\delta \varepsilon \hat{v}$ is the singular of $\delta \varepsilon v \hat{\tau} \varepsilon$; see P.J. Parsons, P.Oxy. LXXIX 5189 . $16 \mathrm{n}$.

\section{To Anatolius, comes, from Colluthus, exceptor}

BL Pap. 1069a

$15.8(w) \times 9.4(h) \mathrm{cm}$

Early seventh century

The text was described in P.Lond. III, p. 1v, as a 'Guarantee or bail for a certain individual. 6th or 7 th cent. Imperfect, wanting the right-hand por- 
tion; in a large, sloping, cursive hand'. The sheet was broken along the middle part, as suggested by the remains of the inked seal.

Colluthus, an exceptor, informs the comes Anatolius of the arrest and imprisonment of a man in his employ, and requests his release. This is a common topic in comunications of the later period, especially after the Conquest (cf. F. Morelli, CPR XXX 24 introd.). Colluthus may well be known from other Hermopolite documents of this date. There are three entries for payments by a Colluthus, exceptor, in P.Sorb. II 69, and one of them (91.A3) suggests that he was an Antinoite; a shorthand writer, he would have been on the staff of the praeses of the Thebaid or the dux in Antinoopolis. A Fl. Colluthus, exceptor, signs as a witness in P.Laur. II $26.25-6\left(609 / 10^{15}\right)$, but his hand is not the same as that responsible for this letter.

The papyrus was purchased from Ch. Murch on 8 June 1901.

\begin{tabular}{|c|c|c|}
\hline$\downarrow$ & 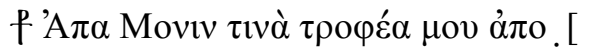 & c. 27 \\
\hline & 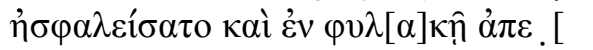 & c. 27 \\
\hline & 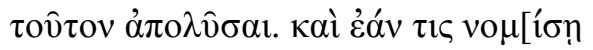 & $c .25$ \\
\hline 4 & $\lambda$ & c. 25 \\
\hline
\end{tabular}

Back:

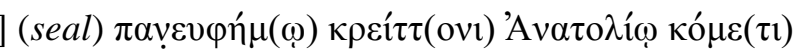

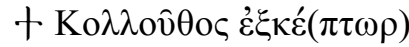

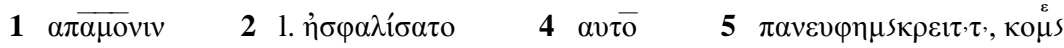

$6 \varepsilon \xi \kappa^{\varepsilon}$

'... arrested ... a certain Apa Monis, a foster-father of mine from(?) ... and ... in prison ... to release him. And if someone thinks ... an account, I make a defence for him ...'

Back: 'To the ... all-renowned, powerful Anatolius, comes: Colluthus, exceptor.'

1 'A $\pi \alpha$ Moviv. The long line over the name may mark it as non-Greek. The name Movis (spelled variously) is typical of the area of Hermopolis; see J. Gascou, P.Sorb. II 69.35.16 n.

${ }^{15}$ I briefly discuss the date of this text in 'Prosopographica II', APF 55 (2009) 93f. 


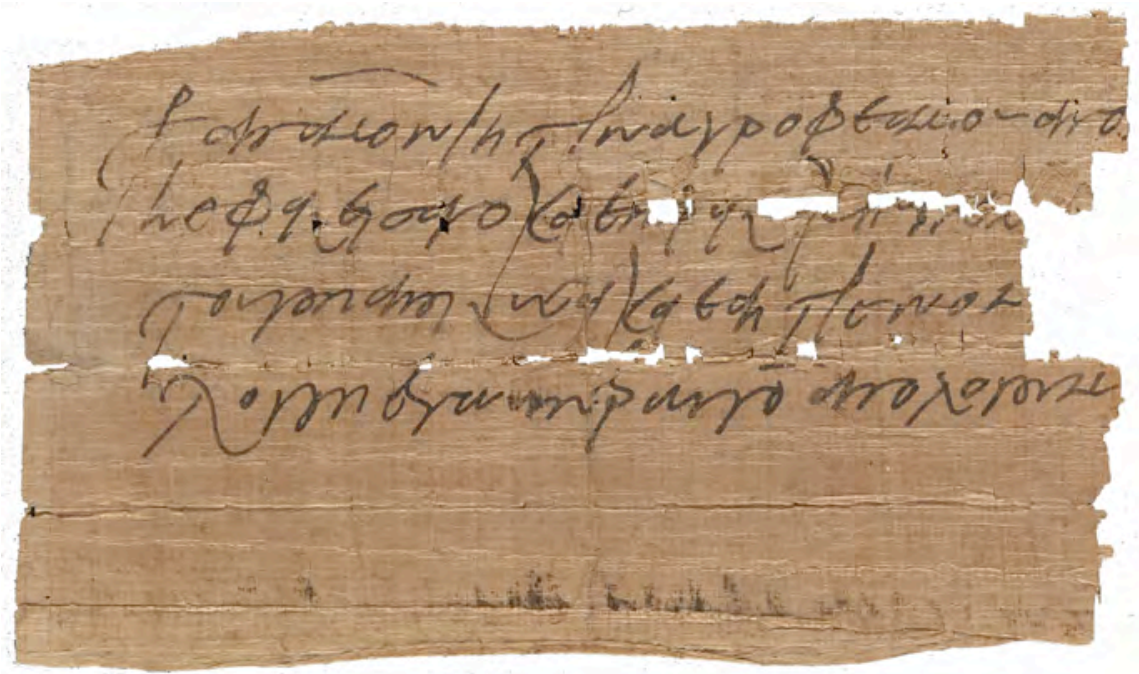

P.Lond. III, p. Iv (BL Pap. 1069a r)

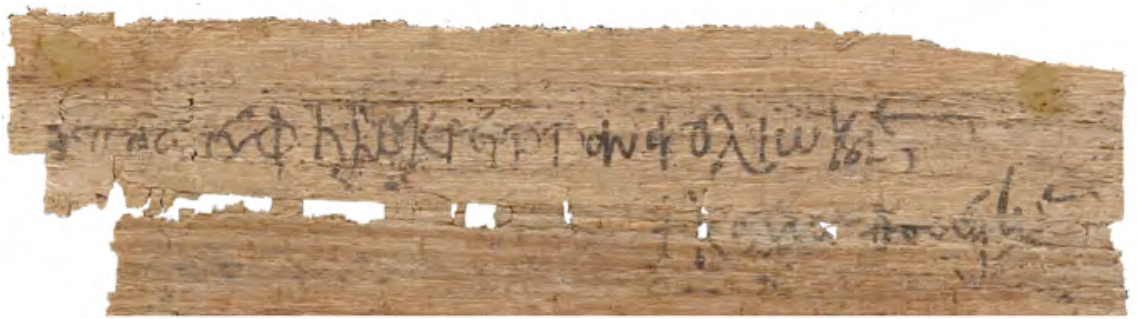

P.Lond. III, p. lv (BL Pap. 106 9a v)

$\tau \rho о \varphi \varepsilon ́ \alpha \mu$ ov. The word refers to a 'foster-father'; see Lampe, $P G L$ s.v. $\tau \rho о \varphi \varepsilon v ́ c$, and P.Sorb. II 69, p. 52, n. 203. The possessive pronoun indicates that this was an employee of the writer.

$2 \dot{\alpha} \pi \varepsilon$. [. Perhaps $\dot{\alpha} \pi \varepsilon \kappa[[\lambda-$, but the fibres are disturbed and cannot confirm it.

$3 \dot{\alpha} \pi \mathrm{o} \lambda \hat{v} \sigma \alpha \mathrm{l}$ would have been governed by an imperative such as $\theta \dot{\varepsilon} \lambda \eta \sigma o v$, lost at the end of 1. 2.

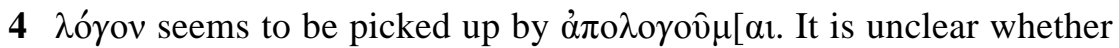

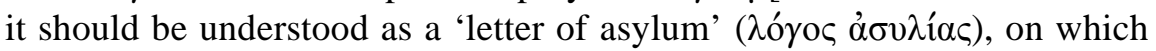
see R.S. Bagnall \& B. Palme, 'Franks in Sixth-century Egypt', Tyche 11 (1996) 2-4. 


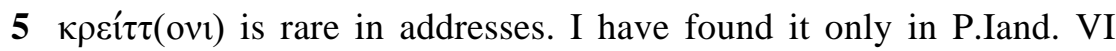
133v and P.Oxy. I 128.15, also after $\pi \alpha v \varepsilon v \varphi n \mu \omega$, and in PSI I 97v, where the abbreviation was left unresolved.

6 Ko $\lambda \lambda$ ov̂$\theta$ oc $\dot{\varepsilon} \xi \kappa \varepsilon(\pi \tau \omega \rho)$. See P.Sorb. II 69.5.4 n., and above, introd. On the function, see J.R. Rea, P.Oxy. LVIII 3932.16 n., who points out that exceptores could also serve at the offices of state functionaries other than praesides and duces; cf. also P.Aphrod.Lit. IV 8, addressed to an exceptor of the praerorian prefects. Several other exceptores occur in P.Sorb. II 69. 